\title{
Melatonin receptors (version 2019.4) in the IUPHAR/BPS Guide to Pharmacology Database
} \author{
Darius Paul Zlotos $^{12}$ \\ 1. Pontificia Universidad Católica Argentina Buenos Aires, Argentina \\ 2. Servier, France \\ 3. University at Buffalo (SUNY), USA \\ 4. Université Paris Descartes, France \\ 5. University of California Irvine, USA \\ 6. University of São Paulo, Brazil \\ 7. Florida State University, USA \\ 8. Universidad Complutense de Madrid, Spain \\ 9. Université Lille 2, France \\ 10. King's College London, UK \\ 11. Morehouse School of Medicine, USA \\ 12. German University in Cairo, Egypt
}

Daniel P. Cardinali ${ }^{1}$, Philippe Delagrange ${ }^{2}$, Margarita L. Dubocovich ${ }^{3}$, Ralf Jockers ${ }^{4}$, Diana N. Krause ${ }^{5}$, Regina Pekelmann Markus $^{6}$, James Olcese ${ }^{7}$, Jesús Pintor ${ }^{8}$, Nicolas Renault ${ }^{9}$, David Sugden ${ }^{10}$, Gianluca Tosini ${ }^{11}$ and

\begin{abstract}
Melatonin receptors (nomenclature as agreed by the NC-IUPHAR Subcommittee on Melatonin Receptors [36]) are activated by the endogenous ligands melatonin and clinically used drugs like ramelteon, agomelatine and tasimelteon.
\end{abstract}

\section{Contents}

This is a citation summary for Melatonin receptors in the Guide to Pharmacology database (GtoPdb). It exists purely as an adjunct to the database to facilitate the recognition of citations to and from the database by citation analyzers. Readers will almost certainly want to visit the relevant sections of the database which are given here under database links.

GtoPdb is an expert-driven guide to pharmacological targets and the substances that act on them. GtoPdb is a reference work which is most usefully represented as an on-line database. As in any publication this work should be appropriately cited, and the papers it cites should also be recognized. This document provides a citation for the relevant parts of the database, and also provides a reference list for the research cited by those parts.

Please note that the database version for the citations given in GtoPdb are to the most recent preceding version in which the family or its subfamilies and targets were substantially changed. The links below are to the current version. If you need to consult the cited version, rather than the most recent version, please contact the GtoPdb curators. 


\section{Database links}

\section{Melatonin receptors}

http://www.guidetopharmacology.org/GRAC/FamilyDisplayForward?familyld=39

Introduction to Melatonin receptors

http://www.guidetopharmacology.org/GRAC/FamilyIntroductionForward?familyld=39

Receptors

$\mathrm{MT}_{1}$ receptor

http://www.guidetopharmacology.org/GRAC/ObjectDisplayForward?objectld=287

$\mathrm{MT}_{2}$ receptor

http://www.guidetopharmacology.org/GRAC/ObjectDisplayForward?objectld=288

\section{References}

1. Al-Ghoul WM, Herman MD and Dubocovich ML. (1998) Melatonin receptor subtype expression in human cerebellum. Neuroreport 9: 4063-8 [PMID:9926848]

2. Andersson EA, Holst B, Sparsø T, Grarup N, Banasik K, Holmkvist J, Jørgensen T, Borch-Johnsen K, Egerod KL and Lauritzen T et al.. (2010) MTNR1B G24E variant associates With BMI and fasting plasma glucose in the general population in studies of 22,142 Europeans. Diabetes 59: 1539-48 [PMID:20200315]

3. AstraZeneca. AZD7325.

4. Audinot V, Bonnaud A, Grandcolas L, Rodriguez M, Nagel N, Galizzi JP, Balik A, Messager S, Hazlerigg DG and Barrett $P$ et al.. (2008) Molecular cloning and pharmacological characterization of rat melatonin MT1 and MT2 receptors. Biochem. Pharmacol. 75: 2007-19 [PMID:18384758]

5. Audinot V, Mailliet F, Lahaye-Brasseur C, Bonnaud A, Le Gall A, Amossé C, Dromaint S, Rodriguez M, Nagel N and Galizzi JP et al.. (2003) New selective ligands of human cloned melatonin MT1 and MT2 receptors. Naunyn Schmiedebergs Arch. Pharmacol. 367: 553-61 [PMID:12764576]

6. Ayoub MA, Couturier C, Lucas-Meunier E, Angers S, Fossier P, Bouvier M and Jockers R. (2002) Monitoring of ligand-independent dimerization and ligand-induced conformational changes of melatonin receptors in living cells by bioluminescence resonance energy transfer. J. Biol. Chem. 277: 21522-8 [PMID:11940583]

7. Ayoub MA, Levoye A, Delagrange P and Jockers R. (2004) Preferential formation of MT1/MT2 melatonin receptor heterodimers with distinct ligand interaction properties compared with MT2 homodimers. Mol. Pharmacol. 66: 312-21 [PMID:15266022]

8. Baba K, Benleulmi-Chaachoua A, Journé AS, Kamal M, Guillaume JL, Dussaud S, Gbahou F, Yettou K, Liu C and Contreras-Alcantara S et al.. (2013) Heteromeric MT1/MT2 melatonin receptors modulate photoreceptor function. Sci Signa/ 6: ra89 [PMID:24106342]

9. Baba K, Pozdeyev N, Mazzoni F, Contreras-Alcantara S, Liu C, Kasamatsu M, Martinez-Merlos T, Strettoi E, luvone PM and Tosini G. (2009) Melatonin modulates visual function and cell viability in the mouse retina via the MT1 melatonin receptor. Proc. Natl. Acad. Sci. U.S.A. 106: 15043-8 [PMID:19706469]

10. Barrett $P$, Conway S, Jockers R, Strosberg AD, Guardiola-Lemaitre B, Delagrange $P$ and Morgan PJ. (1997) Cloning and functional analysis of a polymorphic variant of the ovine Mel 1a melatonin receptor. Biochim. Biophys. Acta 1356: 299-307 [PMID:9194573]

11. Beresford IJ, Browning C, Starkey SJ, Brown J, Foord SM, Coughlan J, North PC, Dubocovich ML and Hagan RM. (1998) GR196429: a nonindolic agonist at high-affinity melatonin receptors. J. Pharmacol. Exp. Ther. 285: 1239-45 [PMID:9618428]

12. Beresford IJ, Harvey FJ, Hall DA and Giles H. (1998) Pharmacological characterisation of melatonin mt1 receptor-mediated stimulation of [35S]-GTPgammaS binding. Biochem. Pharmacol. 56: 1167-74 [PMID:9802327]

13. Blask DE, Brainard GC, Dauchy RT, Hanifin JP, Davidson LK, Krause JA, Sauer LA, Rivera-Bermudez MA, Dubocovich ML and Jasser SA et al.. (2005) Melatonin-depleted blood from premenopausal women exposed to light at night stimulates growth of human breast cancer xenografts in nude rats. Cancer Res. 
65: 11174-84 [PMID:16322268]

14. Blask DE, Dauchy RT, Sauer LA, Krause JA and Brainard GC. (2002) Light during darkness, melatonin suppression and cancer progression. Neuro Endocrinol. Lett. 23 Suppl 2: 52-6 [PMID:12163849]

15. Bonnefond A, Clément N, Fawcett K, Yengo L, Vaillant E, Guillaume JL, Dechaume A, Payne F, Roussel $\mathrm{R}$ and Czernichow $\mathrm{S}$ et al.. (2012) Rare MTNR1B variants impairing melatonin receptor 1B function contribute to type 2 diabetes. Nat. Genet. 44: 297-301 [PMID:22286214]

16. Browning C, Beresford I, Fraser N and Giles H. (2000) Pharmacological characterization of human recombinant melatonin $\mathrm{mt}(1)$ and MT(2) receptors. Br. J. Pharmacol. 129: 877-86 [PMID:10696085]

17. Brydon L, Petit L, Delagrange P, Strosberg AD and Jockers R. (2001) Functional expression of MT2 (Mel1b) melatonin receptors in human PAZ6 adipocytes. Endocrinology 142: 4264-71 [PMID:11564683]

18. Carrillo-Vico A, García-Mauriño S, Calvo JR and Guerrero JM. (2003) Melatonin counteracts the inhibitory effect of PGE2 on IL-2 production in human lymphocytes via its mt1 membrane receptor. FASEB J. 17: 755-7 [PMID:12594180]

19. Chaste P, Clement N, Botros HG, Guillaume JL, Konyukh M, Pagan C, Scheid I, Nygren G, Anckarsäter H and Rastam $M$ et al.. (2011) Genetic variations of the melatonin pathway in patients with attention-deficit and hyperactivity disorders. J. Pineal Res. 51: 394-9 [PMID:21615493]

20. Chaste P, Clement N, Mercati O, Guillaume JL, Delorme R, Botros HG, Pagan C, Périvier S, Scheid I, Nygren G, Anckarsäter H, Rastam M, Ståhlberg O, Gillberg C, Serrano E, Lemière N, Launay JM, MourenSimeoni MC, Leboyer M, Gillberg C, Jockers R and Bourgeron T. (2010) Identification of pathway-biased and deleterious melatonin receptor mutants in autism spectrum disorders and in the general population. PLoS ONE 5: e11495 [PMID:20657642]

21. Cogé F, Guenin SP, Fery I, Migaud M, Devavry S, Slugocki C, Legros C, Ouvry C, Cohen W and Renault $\mathrm{N}$ et al.. (2009) The end of a myth: cloning and characterization of the ovine melatonin MT(2) receptor $B r$. J. Pharmacol. 158: 1248-62 [PMID:19814723]

22. Contreras-Alcantara S, Baba K and Tosini G. (2010) Removal of melatonin receptor type 1 induces insulin resistance in the mouse. Obesity (Silver Spring) 18: 1861-3 [PMID:20168308]

23. Conway S, Drew JE, Canning SJ, Barrett $P$, Jockers R, Strosberg AD, Guardiola-Lemaitre B, Delagrange $P$ and Morgan PJ. (1997) Identification of Mel1a melatonin receptors in the human embryonic kidney cell line HEK293: evidence of $G$ protein-coupled melatonin receptors which do not mediate the inhibition of stimulated cyclic AMP levels. FEBS Lett. 407: 121-6 [PMID:9141494]

24. Copinga S, Tepper PG, Grol CJ, Horn AS and Dubocovich ML. (1993) 2-Amido-8-methoxytetralins: a series of nonindolic melatonin-like agents. J. Med. Chem. 36: 2891-8 [PMID:8411005]

25. Depreux P, Lesieur D, Mansour HA, Morgan P, Howell HE, Renard P, Caignard DH, Pfeiffer B, Delagrange $P$ and Guardiola $B$ et al.. (1994) Synthesis and structure-activity relationships of novel naphthalenic and bioisosteric related amidic derivatives as melatonin receptor ligands. J. Med. Chem. 37: 3231-9 [PMID:7932550]

26. Devavry S, Legros C, Brasseur C, Delagrange P, Spadoni G, Cohen W, Malpaux B, Boutin JA and Nosjean O. (2012) Description of the constitutive activity of cloned human melatonin receptors hMT(1) and hMT(2) and discovery of inverse agonists. J. Pineal Res. 53: 29-37 [PMID:22017484]

27. Doolen S, Krause DN, Dubocovich ML and Duckles SP. (1998) Melatonin mediates two distinct responses in vascular smooth muscle. Eur. J. Pharmacol. 345: 67-9 [PMID:9593596]

28. Drazen DL, Bilu D, Bilbo SD and Nelson RJ. (2001) Melatonin enhancement of splenocyte proliferation is attenuated by luzindole, a melatonin receptor antagonist. Am. J. Physiol. Regul. Integr. Comp. Physiol. 280: R1476-82 [PMID:11294771]

29. Drazen DL and Nelson RJ. (2001) Melatonin receptor subtype MT2 (Mel 1b) and not mt1 (Mel 1a) is associated with melatonin-induced enhancement of cell-mediated and humoral immunity. Neuroendocrinology 74: 178-84 [PMID:11528219]

30. Drew JE, Williams LM, Hannah LT, Barrett P and Abramovich DR. (1998) Melatonin receptors in the human fetal kidney: 2-[125I]iodomelatonin binding sites correlated with expression of Mel1a and Mel1b receptor genes. J. Endocrinol. 156: 261-7 [PMID:9518871] 
31. Dubocovich ML. (1985) Characterization of a retinal melatonin receptor.J. Pharmacol. Exp. Ther. 234: 395-401 [PMID:2991499]

32. Dubocovich ML. (2007) Melatonin receptors: role on sleep and circadian rhythm regulation. Sleep Med. 8 Suppl 3: 34-42 [PMID:18032103]

33. Dubocovich ML. (1988) Luzindole (N-0774): a novel melatonin receptor antagonist.J. Pharmacol. Exp. Ther. 246: 902-10 [PMID:2843633]

34. Dubocovich ML. (1988) Pharmacology and function of melatonin receptors. FASEB J. 2: 2765-73 [PMID:2842214]

35. Dubocovich ML. (1995) Melatonin receptors: are there multiple subtypes?Trends Pharmacol. Sci. 16: 50-6 [PMID:7762083]

36. Dubocovich ML, Delagrange P, Krause DN, Sugden D, Cardinali DP and Olcese J. (2010) International Union of Basic and Clinical Pharmacology. LXXV. Nomenclature, classification, and pharmacology of G protein-coupled melatonin receptors. Pharmacol. Rev. 62: 343-80 [PMID:20605968]

37. Dubocovich ML, Hudson RL, Sumaya IC, Masana MI and Manna E. (2005) Effect of MT1 melatonin receptor deletion on melatonin-mediated phase shift of circadian rhythms in the C57BL/6 mouse. J. Pineal Res. 39: 113-20 [PMID:16098087]

38. Dubocovich ML and Markowska M. (2005) Functional MT1 and MT2 melatonin receptors in mammals. Endocrine 27: 101-10 [PMID:16217123]

39. Dubocovich ML and Masana MI. (1998) The efficacy of melatonin receptor analogues is dependent on the level of human melatonin receptor subtype expression. In Biological Clocks, Mechanisms and Applications. Edited by Touitou Y: Elsevier Science B. V.: 289-293 [ISBN: 0444825037]

40. Dubocovich ML, Masana MI, lacob S and Sauri DM. (1997) Melatonin receptor antagonists that differentiate between the human Mel1a and Mel1b recombinant subtypes are used to assess the pharmacological profile of the rabbit retina ML1 presynaptic heteroreceptor. Naunyn Schmiedebergs Arch. Pharmacol. 355: 365-75 [PMID:9089668]

41. Dubocovich ML, Rivera-Bermudez MA, Gerdin MJ and Masana MI. (2003) Molecular pharmacology, regulation and function of mammalian melatonin receptors. Front. Biosci. 8: d1093-108 [PMID:12957828]

42. Dubocovich ML, Yun K, Al-Ghoul WM, Benloucif S and Masana MI. (1998) Selective MT2 melatonin receptor antagonists block melatonin-mediated phase advances of circadian rhythms. FASEB J.12: 121120 [PMID:9737724]

43. Dufourny L, Levasseur A, Migaud M, Callebaut I, Pontarotti P, Malpaux B and Monget P. (2008) GPR50 is the mammalian ortholog of Mel1c: evidence of rapid evolution in mammals. BMC Evol. Biol. 8: 105 [PMID:18400093]

44. Duncan MJ, Takahashi JS and Dubocovich ML. (1988) 2-[1251]iodomelatonin binding sites in hamster brain membranes: pharmacological characteristics and regional distribution. Endocrinology 122: 1825-33 [PMID:2834175]

45. Duncan MJ, Takahashi JS and Dubocovich ML. (1989) Characteristics and autoradiographic localization of 2-[125I]iodomelatonin binding sites in Djungarian hamster brain. Endocrinology 125: 1011-8 [PMID:2752961]

46. Ebisawa T, Kajimura N, Uchiyama M, Katoh M, Sekimoto M, Watanabe T, Ozeki Y, Ikeda M, Jodoi T and Sugishita M et al.. (1999) Alleic variants of human melatonin 1a receptor: function and prevalence in subjects with circadian rhythm sleep disorders. Biochem. Biophys. Res. Commun. 262: 832-7 [PMID:10471411]

47. Ebisawa T, Uchiyama M, Kajimura N, Kamei Y, Shibui K, Kim K, Kudo Y, Iwase T, Sugishita M and Jodoi T et al.. (2000) Genetic polymorphisms of human melatonin $1 \mathrm{~b}$ receptor gene in circadian rhythm sleep disorders and controls. Neurosci. Lett. 280: 29-32 [PMID:10696804]

48. Eison AS and Mullins UL. (1993) Melatonin binding sites are functionally coupled to phosphoinositide hydrolysis in Syrian hamster RPMI 1846 melanoma cells. Life Sci. 53: PL393-8 [PMID:8246675]

49. Ekmekcioglu C, Haslmayer P, Philipp C, Mehrabi MR, Glogar HD, Grimm M, Leibetseder VJ, Thalhammer T and Marktl W. (2001) Expression of the MT1 melatonin receptor subtype in human coronary arteries. J. 
Recept. Signal Transduct. Res. 21: 85-91 [PMID:11693175]

50. Ekmekcioglu C, Haslmayer P, Philipp C, Mehrabi MR, Glogar HD, Grimm M, Thalhammer T and Marktl W. (2001) 24h variation in the expression of the $\mathrm{mt} 1$ melatonin receptor subtype in coronary arteries derived from patients with coronary heart disease. Chronobiol. Int. 18: 973-85 [PMID:11777084]

51. Erşahin C, Masana MI and Dubocovich ML. (2002) Constitutively active melatonin MT(1) receptors in male rat caudal arteries. Eur. J. Pharmacol. 439: 171-2 [PMID:11937107]

52. Ettaoussi M, Sabaouni A, Rami M, Boutin JA, Delagrange P, Renard P, Spedding M, Caignard DH, Berthelot $P$ and Yous S. (2012) Design, synthesis and pharmacological evaluation of new series of naphthalenic analogues as melatoninergic (MT1/MT2) and serotoninergic 5-HT2C dual ligands (I). Eur $J$ Med Chem 49: 310-23 [PMID:22301214]

53. Faust R, Garratt PJ, Jones R, Yeh LK, Tsotinis A, Panoussopoulou M, Calogeropoulou T, Teh MT and Sugden D. (2000) Mapping the melatonin receptor. 6. Melatonin agonists and antagonists derived from 6H-isoindolo[2,1-a]indoles, 5,6-dihydroindolo[2,1-a]isoquinolines, and 6,7-dihydro-5H-benzo[c]azepino[2,1a]indoles. J. Med. Chem. 43: 1050-61 [PMID:10737738]

54. Flaugh ME, Crowell TA, Clemens JA and Sawyer BD. (1979) Synthesis and evaluation of the antiovulatory activity of a variety of melatonin analogues. J. Med. Chem. 22: 63-9 [PMID:423184]

55. Garratt PJ, Jones R, Tocher DA and Sugden D. (1995) Mapping the melatonin receptor. 3. Design and synthesis of melatonin agonists and antagonists derived from 2-phenyltryptamines. J. Med. Chem. 38: 1132-9 [PMID:7707316]

56. Garratt PJ, Travard S, Vonhoff S, Tsotinis A and Sugden D. (1996) Mapping the melatonin receptor. 4. Comparison of the binding affinities of a series of substituted phenylalkyl amides. J. Med. Chem. 39: 1797805 [PMID:8627603]

57. Garrett PJ, Jones R, Rowe SJ and Sugden D. (1994) Mapping the melatonin receptor. 1. The 5-methoxyl group of melatonin is not an essential requirement for biological activity. Bioorg. Med. Chem. Lett. 4: 15551558

58. Garrett PJ, Vonhoff S, Rowe S and Sugden D. (1994) Mapping of the melatonin receptor. 2. Synthesis and biological activity of indole derived melatonin analogues with restricted conformations of the C-3 amido ethane side chain. Bioorg. Med. Chem. Lett. 4: 1559-1564

59. Geary GG, Duckles SP and Krause DN. (1998) Effect of melatonin in the rat tail artery: role of K+ channels and endothelial factors. Br. J. Pharmacol. 123: 1533-40 [PMID:9605558]

60. Geary GG, Krause DN and Duckles SP. (1997) Melatonin directly constricts rat cerebral arteries through modulation of potassium channels. Am. J. Physiol. 273: H1530-6 [PMID:9321846]

61. Godson C and Reppert SM. (1997) The Mel1a melatonin receptor is coupled to parallel signal transduction pathways. Endocrinology 138: 397-404 [PMID:8977429]

62. Hagan RM and Oakley NR. (1995) Melatonin comes of age? Trends Pharmacol. Sci. 16: 81-3 [PMID:7792932]

63. Hu Y, Zhu J, Chan KH and Wong YH. (2013) Development of substituted N-[3-(3-methoxylphenyl)propyl] amides as MT(2)-selective melatonin agonists: improving metabolic stability. Bioorg. Med. Chem. 21: 54752 [PMID:23228808]

64. Huete-Toral F, Crooke A, Martínez-Águila A and Pintor J. (2015) Melatonin receptors trigger cAMP production and inhibit chloride movements in nonpigmented ciliary epithelial cells. J. Pharmacol. Exp. Ther. 352: 119-28 [PMID:25344385]

65. Hunt AE, Al-Ghoul WM, Gillette MU and Dubocovich ML. (2001) Activation of MT(2) melatonin receptors in rat suprachiasmatic nucleus phase advances the circadian clock. Am. J. Physiol., Cell Physiol. 280: C1108 [PMID:11121382]

66. Jilg A, Moek J, Weaver DR, Korf HW, Stehle JH and von Gall C. (2005) Rhythms in clock proteins in the mouse pars tuberalis depend on MT1 melatonin receptor signalling. Eur. J. Neurosci. 22: 2845-54 [PMID:16324119]

67. Jin X, von Gall C, Pieschl RL, Gribkoff VK, Stehle JH, Reppert SM and Weaver DR. (2003) Targeted disruption of the mouse Mel(1b) melatonin receptor. Mol. Cell. Biol. 23: 1054-60 [PMID:12529409] 
68. Jockers R, Maurice P, Boutin JA and Delagrange P. (2008) Melatonin receptors, heterodimerization, signal transduction and binding sites: what's new? Br. J. Pharmacol. 154: 1182-95 [PMID:18493248]

69. Johnston JD, Messager S, Barrett P and Hazlerigg DG. (2003) Melatonin action in the pituitary: neuroendocrine synchronizer and developmental modulator? J. Neuroendocrinol. 15: 405-8 [PMID:12622841]

70. Johnston JD, Messager S, Ebling FJ, Williams LM, Barrett P and Hazlerigg DG. (2003) Gonadotrophinreleasing hormone drives melatonin receptor down-regulation in the developing pituitary gland. Proc Natl Acad Sci U S A 100: 2831-2835 [PMID:12598657]

71. Karamitri A and Jockers R. (2019) Melatonin in type 2 diabetes mellitus and obesity Nat Rev Endocrinol 15: 105-125 [PMID:30531911]

72. Karamitri A, Renault N, Clement N, Guillaume JL and Jockers R. (2013) Minireview: Toward the establishment of a link between melatonin and glucose homeostasis: association of melatonin MT2 receptor variants with type 2 diabetes. Mol. Endocrinol. 27: 1217-33 [PMID:23798576]

73. Kato K, Hirai K, Nishiyama K, Uchikawa O, Fukatsu K, Ohkawa S, Kawamata Y, Hinuma S and Miyamoto M. (2005) Neurochemical properties of ramelteon (TAK-375), a selective MT1/MT2 receptor agonist. Neuropharmacology 48: 301-10 [PMID:15695169]

74. Kemp DM, Ubeda M and Habener JF. (2002) Identification and functional characterization of melatonin Mel 1a receptors in pancreatic beta cells: potential role in incretin-mediated cell function by sensitization of CAMP signaling. Mol. Cell. Endocrinol. 191: 157-66 [PMID:12062899]

75. Koike T, Hoashi Y, Takai T, Nakayama M, Yukuhiro N, Ishikawa T, Hirai K and Uchikawa O. (2011) 1,6Dihydro-2H-indeno[5,4-b]furan derivatives: design, synthesis, and pharmacological characterization of a novel class of highly potent $\mathrm{MT}_{2}$-selective agonists. J. Med. Chem. 54: 3436-44 [PMID:21473625]

76. Koike T, Takai T, Hoashi Y, Nakayama M, Kosugi Y, Nakashima M, Yoshikubo S, Hirai K and Uchikawa O. (2011) Synthesis of a novel series of tricyclic dihydrofuran derivatives: discovery of 8,9-dihydrofuro[3,2c]pyrazolo[1,5-a]pyridines as melatonin receptor (MT1/MT2) ligands. J. Med. Chem. 54: 4207-18 [PMID:21568291]

77. Krause DN, Barrios VE and Duckles SP. (1995) Melatonin receptors mediate potentiation of contractile responses to adrenergic nerve stimulation in rat caudal artery. Eur. J. Pharmacol. 276: 207-13 [PMID:7601206]

78. Krause DN and Dubocovich ML. (1990) Regulatory sites in the melatonin system of mammals.Trends Neurosci. 13: 464-470 [PMID:1701580]

79. Lanoix D, Ouellette R and Vaillancourt C. (2006) Expression of melatoninergic receptors in human placental choriocarcinoma cell lines. Hum. Reprod. 21: 1981-9 [PMID:16632463]

80. Lardone PJ, Rubio A, Cerrillo I, Gómez-Corvera A, Carrillo-Vico A, Sanchez-Hidalgo M, Guerrero JM, Fernandez-Riejos P, Sanchez-Margalet $V$ and Molinero P. (2010) Blocking of melatonin synthesis and MT(1) receptor impairs the activation of Jurkat T cells. Cell. Mol. Life Sci. 67: 3163-72 [PMID:20440532]

81. Legros C, Matthey U, Grelak T, Pedragona-Moreau S, Hassler W, Yous S, Thomas E, Suzenet F, Folleas B and Lefoulon F et al.. (2013) New Radioligands for Describing the Molecular Pharmacology of MT1 and MT2 Melatonin Receptors. Int J Mol Sci 14: 8948-62 [PMID:23698757]

82. Levoye A, Dam J, Ayoub MA, Guillaume JL, Couturier C, Delagrange P and Jockers R. (2006) The orphan GPR50 receptor specifically inhibits MT1 melatonin receptor function through heterodimerization. EMBO J. 25: 3012-23 [PMID:16778767]

83. Liu C, Weaver DR, Jin X, Shearman LP, Pieschl RL, Gribkoff VK and Reppert SM. (1997) Molecular dissection of two distinct actions of melatonin on the suprachiasmatic circadian clock. Neuron 19: 91-102 [PMID:9247266]

84. Lucchelli A, Santagostino-Barbone MG and Tonini M. (1997) Investigation into the contractile response of melatonin in the guinea-pig isolated proximal colon: the role of 5-HT4 and melatonin receptors. Br. J. Pharmacol. 121: 1775-81 [PMID:9283717]

85. Lucini V, Pannacci M, Scaglione F, Fraschini F, Rivara S, Mor M, Bordi F, Plazzi PV, Spadoni G and Bedini A et al.. (2004) Tricyclic alkylamides as melatonin receptor ligands with antagonist or inverse 
agonist activity. J. Med. Chem. 47: 4202-12 [PMID:15293992]

86. MacKenzie RS, Melan MA, Passey DK and Witt-Enderby PA. (2002) Dual coupling of MT(1) and MT(2) melatonin receptors to cyclic AMP and phosphoinositide signal transduction cascades and their regulation following melatonin exposure. Biochem. Pharmacol. 63: 587-95 [PMID:11992626]

87. Mahle CD, Goggins GD, Agarwal P, Ryan E and Watson AJ. (1997) Melatonin modulates vascular smooth muscle tone. J. Biol. Rhythms 12: 690-6 [PMID:9406046]

88. Mailliet F, Audinot V, Malpaux B, Bonnaud A, Delagrange P, Migaud M, Barrett P, Viaud-Massuard MC, Lesieur D and Lefoulon F et al.. (2004) Molecular pharmacology of the ovine melatonin receptor: comparison with recombinant human MT1 and MT2 receptors. Biochem. Pharmacol. 67: 667-77 [PMID:14757166]

89. Mailliet F, Ferry G, Vella F, Thiam K, Delagrange $P$ and Boutin JA. (2004) Organs from mice deleted for $\mathrm{NRH}$ :quinone oxidoreductase 2 are deprived of the melatonin binding site MT3. FEBS Lett 578: 116-120 [PMID:15581627]

90. Markus RP, Cecon E and Pires-Lapa MA. (2013) Immune-Pineal Axis: Nuclear Factor kB (NF-kB) Mediates the Shift in the Melatonin Source from Pinealocytes to Immune Competent Cells. Int $J$ Mol Sci 14: 10979-97 [PMID:23708099]

91. Masana MI, Doolen S, Ersahin C, Al-Ghoul WM, Duckles SP, Dubocovich ML and Krause DN. (2002) MT(2) melatonin receptors are present and functional in rat caudal artery. $J$ Pharmacol Exp Ther 302: 1295-1302 [PMID:12183692]

92. Masana MI and Dubocovich ML. (2001) Melatonin receptor signaling: finding the path through the dark. SCi. STKE 2001: pe39 [PMID:11698691]

93. Mazzucchelli C, Pannacci M, Nonno R, Lucini V, Fraschini F and Stankov BM. (1996) The melatonin receptor in the human brain: cloning experiments and distribution studies. Brain Res. Mol. Brain Res. 39: 117-26 [PMID:8804720]

94. Molinari EJ, North PC and Dubocovich ML. (1996) 2-[125I]iodo-5-methoxycarbonylamino-Nacetyltryptamine: a selective radioligand for the characterization of melatonin ML2 binding sites. Eur. $J$. Pharmacol. 301: 159-68 [PMID:8773460]

95. Morellato L, Lefas-Le Gall M, Langlois M, Caignard DH, Renard P, Delagrange P and Mathé-Allainmat M. (2013) Synthesis of new N-(arylcyclopropyl)acetamides and N-(arylvinyl)acetamides as conformationallyrestricted ligands for melatonin receptors. Bioorg. Med. Chem. Lett. 23: 430-4 [PMID:23265885]

96. Morgan PJ, Barrett P, Howell HE and Helliwell R. (1994) Melatonin receptors: localization, molecular pharmacology and physiological significance. Neurochem. Int. 24: 101-46 [PMID:8161940]

97. Mulchahey JJ, Goldwater DR and Zemlan FP. (2004) A single blind, placebo controlled, across groups dose escalation study of the safety, tolerability, pharmacokinetics and pharmacodynamics of the melatonin analog beta-methyl-6-chloromelatonin. Life Sci. 75: 1843-56 [PMID:15302228]

98. Mésangeau C, Pérès B, Descamps-François $C$, Chavatte $P$, Audinot V, Coumailleau $S$, Boutin JA, Delagrange P, Bennejean C and Renard P et al.. (2010) Design, synthesis and pharmacological evaluation of novel naphthalenic derivatives as selective MT(1) melatoninergic ligands. Bioorg. Med. Chem. 18: 342636 [PMID:20444610]

99. Mühlbauer E, Gross E, Labucay K, Wolgast S and Peschke E. (2009) Loss of melatonin signalling and its impact on circadian rhythms in mouse organs regulating blood glucose. Eur. J. Pharmacol. 606: 61-71 [PMID:19374844]

100. Naji L, Carrillo-Vico A, Guerrero JM and Calvo JR. (2004) Expression of membrane and nuclear melatonin receptors in mouse peripheral organs. Life Sci 74: 2227-2236 [PMID:14987948]

101. Niles LP, Wang J, Shen L, Lobb DK and Younglai EV. (1999) Melatonin receptor mRNA expression in human granulosa cells. Mol. Cell. Endocrinol. 156: 107-10 [PMID:10612428]

102. Nonno R, Lucini V, Spadoni G, Pannacci M, Croce A, Esposti D, Balsamini C, Tarzia G, Fraschini F and Stankov BM. (2000) A new melatonin receptor ligand with mt1-agonist and MT2-antagonist properties. J. Pineal Res. 29: 234-40 [PMID:11068946]

103. Nosjean O, Ferro M, Coge F, Beauverger P, Henlin JM, Lefoulon F, Fauchere JL, Delagrange P, Canet E 
and Boutin JA. (2000) Identification of the melatonin-binding site MT3 as the quinone reductase 2. J. Biol. Chem. 275: 31311-7 [PMID:10913150]

104. Nosjean O, Nicolas JP, Klupsch F, Delagrange P, Canet E and Boutin JA. (2001) Comparative pharmacological studies of melatonin receptors: MT1, MT2 and MT3/QR2. Tissue distribution of MT3/QR2 . Biochem. Pharmacol. 61: 1369-79 [PMID:11331072]

105. Petit L, Lacroix I, de Coppet $P$, Strosberg AD and Jockers R. (1999) Differential signaling of human Mel1a and Mel1b melatonin receptors through the cyclic guanosine 3'-5'-monophosphate pathway. Biochem. Pharmacol. 58: 633-9 [PMID:10413300]

106. Poissonnier-Durieux $S$, Ettaoussi M, Pérès B, Boutin JA, Audinot V, Bennejean $C$, Delagrange $P$, Caignard DH, Renard P and Berthelot $P$ et al.. (2008) Synthesis of 3-phenylnaphthalenic derivatives as new selective MT(2) melatoninergic ligands. Bioorg. Med. Chem. 16: 8339-48 [PMID:18778943]

107. Popova JS and Dubocovich ML. (1995) Melatonin receptor-mediated stimulation of phosphoinositide breakdown in chick brain slices. J. Neurochem. 64: 130-8 [PMID:7798906]

108. Ram PT, Dai J, Yuan L, Dong C, Kiefer TL, Lai L and Hill SM. (2002) Involvement of the mt1 melatonin receptor in human breast cancer. Cancer Lett. 179: 141-50 [PMID:11888668]

109. Rawashdeh O, Hudson RL, Stepien I and Dubocovich ML. (2011) Circadian periods of sensitivity for ramelteon on the onset of running-wheel activity and the peak of suprachiasmatic nucleus neuronal firing rhythms in C3H/HeN mice. Chronobiol. Int. 28: 31-8 [PMID:21182402]

110. Reppert SM, Godson C, Mahle CD, Weaver DR, Slaugenhaupt SA and Gusella JF. (1995) Molecular characterization of a second melatonin receptor expressed in human retina and brain: the Mel1 $\mathrm{b}$ melatonin receptor. Proc. Natl. Acad. Sci. U.S.A. 92: 8734-8 [PMID:7568007]

111. Reppert SM, Weaver DR, Cassone VM, Godson C and Kolakowski Jr LF. (1995) Melatonin receptors are for the birds: molecular analysis of two receptor subtypes differentially expressed in chick brain. Neuron 15: 1003-15 [PMID:7576645]

112. Reppert SM, Weaver DR and Ebisawa T. (1994) Cloning and characterization of a mammalian melatonin receptor that mediates reproductive and circadian responses. Neuron 13: 1177-85 [PMID:7946354]

113. Reppert SM, Weaver DR and Godson C. (1996) Melatonin receptors step into the light: cloning and classification of subtypes. Trends Pharmacol. Sci. 17: 100-2 [PMID:8936344]

114. Rivara S, Lodola A, Mor M, Bedini A, Spadoni G, Lucini V, Pannacci M, Fraschini F, Scaglione F and Sanchez RO et al.. (2007) N-(substituted-anilinoethyl)amides: design, synthesis, and pharmacological characterization of a new class of melatonin receptor ligands. J. Med. Chem. 50: 6618-26 [PMID:18052314]

115. Rivara S, Lorenzi S, Mor M, Plazzi PV, Spadoni G, Bedini A and Tarzia G. (2005) Analysis of structureactivity relationships for MT2 selective antagonists by melatonin MT1 and MT2 receptor models. J. Med. Chem. 48: 4049-60 [PMID:15943478]

116. Rivara S, Mor M, Bedini A, Spadoni G and Tarzia G. (2008) Melatonin receptor agonists: SAR and applications to the treatment of sleep-wake disorders. Curr Top Med Chem 8: 954-68 [PMID:18673165]

117. Rivara S, Pala D, Lodola A, Mor M, Lucini V, Dugnani S, Scaglione F, Bedini A, Lucarini S and Tarzia Cet al.. (2012) MT1-selective melatonin receptor ligands: synthesis, pharmacological evaluation, and molecular dynamics investigation of $\mathrm{N}-\{[(3-\mathrm{O}-$ substituted)anilino]alkyl\}amides. ChemMedChem 7: 1954-64 [PMID:22927210]

118. Roberts JE, Wiechmann AF and Hu DN. (2000) Melatonin receptors in human uveal melanocytes and melanoma cells. J. Pineal Res. 28: 165-71 [PMID:10739303]

119. Roca AL, Godson C, Weaver DR and Reppert SM. (1996) Structure, characterization, and expression of the gene encoding the mouse Mel1a melatonin receptor. Endocrinology 137: 3469-77 [PMID:8754776]

120. Roka F, Brydon L, Waldhoer M, Strosberg AD, Freissmuth M, Jockers R and Nanoff C. (1999) Tight association of the human $\mathrm{Mel}(1 \mathrm{a})$-melatonin receptor and $\mathrm{G}(\mathrm{i})$ : precoupling and constitutive activity. Mol. Pharmacol. 56: 1014-24 [PMID:10531408]

121. Sallinen P, Saarela S, Ilves M, Vakkuri O and Leppäluoto J. (2005) The expression of MT1 and MT2 melatonin receptor mRNA in several rat tissues. Life Sci. 76: 1123-34 [PMID:15620576] 
122. Savaskan E, Ayoub MA, Ravid R, Angeloni D, Fraschini F, Meier F, Eckert A, Müller-Spahn F and Jockers R. (2005) Reduced hippocampal MT2 melatonin receptor expression in Alzheimer's disease. J. Pineal Res. 38: 10-6 [PMID:15617532]

123. Savaskan E, Olivieri G, Brydon L, Jockers R, Kräuchi K, Wirz-Justice A and Müller-Spahn F. (2001) Cerebrovascular melatonin MT1-receptor alterations in patients with Alzheimer's disease. Neurosci. Lett. 308: 9-12 [PMID:11445273]

124. Savaskan E, Wirz-Justice A, Olivieri G, Pache M, Kräuchi K, Brydon L, Jockers R, Müller-Spahn F and Meyer P. (2002) Distribution of melatonin MT1 receptor immunoreactivity in human retina. J. Histochem. Cytochem. 50: 519-26 [PMID:11897804]

125. Scher J, Wankiewicz E, Brown GM and Fujieda H. (2002) MT(1) melatonin receptor in the human retina: expression and localization. Invest. Ophthalmol. Vis. Sci. 43: 889-97 [PMID:11867612]

126. Scher J, Wankiewicz E, Brown GM and Fujieda H. (2003) All amacrine cells express the MT1 melatonin receptor in human and macaque retina. Exp. Eye Res. 77: 375-82 [PMID:12907170]

127. Sengupta A, Baba K, Mazzoni F, Pozdeyev NV, Strettoi E, luvone PM and Tosini G. (2011) Localization of melatonin receptor 1 in mouse retina and its role in the circadian regulation of the electroretinogram and dopamine levels. PLoS ONE 6: e24483 [PMID:21915336]

128. Shiu SY, Li L, Xu JN, Pang CS, Wong JT and Pang SF. (1999) Melatonin-induced inhibition of proliferation and $\mathrm{G} 1 / \mathrm{S}$ cell cycle transition delay of human choriocarcinoma JAr cells: possible involvement of MT2 (MEL1B) receptor. J. Pineal Res. 27: 183-92 [PMID:10535768]

129. Slaugenhaupt SA, Roca AL, Liebert CB, Altherr MR, Gusella JF and Reppert SM. (1995) Mapping of the gene for the Mel1a-melatonin receptor to human chromosome 4 (MTNR1A) and mouse chromosome 8 (Mtnr1a). Genomics 27: 355-7 [PMID:7558006]

130. Soares Jr JM, Masana MI, Erşahin C and Dubocovich ML. (2003) Functional melatonin receptors in rat ovaries at various stages of the estrous cycle. J. Pharmacol. Exp. Ther. 306: 694-702 [PMID:12721330]

131. Spadoni G, Bedini A, Diamantini G, Tarzia G, Rivara S, Lorenzi S, Lodola A, Mor M, Lucini V and Pannacci M et al.. (2007) Synthesis, enantiomeric resolution, and structure-activity relationship study of a series of 10,11-dihydro-5H-dibenzo[a,d]cycloheptene MT2 receptor antagonists. ChemMedChem 2: 17419 [PMID:17907131]

132. Spadoni G, Bedini A, Lucarini S, Mari M, Caignard DH, Boutin JA, Delagrange P, Lucini V, Scaglione F and Lodola A et al.. (2015) Highly Potent and Selective MT2 Melatonin Receptor Full Agonists from Conformational Analysis of 1-Benzyl-2-acylaminomethyl-tetrahydroquinolines. J. Med. Chem. 58: 7512-25 [PMID:26334942]

133. Spadoni G, Stankov B, Duranti A, Biella G, Lucini V, Salvatori A and Fraschini F. (1993) 2-Substituted 5methoxy-N-acyltryptamines: synthesis, binding affinity for the melatonin receptor, and evaluation of the biological activity. J. Med. Chem. 36: 4069-74 [PMID:8258829]

134. Sugden D, Yeh LK and Teh MT. (1999) Design of subtype selective melatonin receptor agonists and antagonists. Reprod. Nutr. Dev. 39: 335-44 [PMID:10420436]

135. Sumaya IC, Masana MI and Dubocovich ML. (2005) The antidepressant-like effect of the melatonin receptor ligand luzindole in mice during forced swimming requires expression of MT2 but not MT1 melatonin receptors. J. Pineal Res. 39: 170-7 [PMID:16098095]

136. Teh MT and Sugden D. (1998) Comparison of the structure-activity relationships of melatonin receptor agonists and antagonists: lengthening the $\mathrm{N}$-acyl side-chain has differing effects on potency on Xenopus melanophores. Naunyn Schmiedebergs Arch. Pharmacol. 358: 522-8 [PMID:9840420]

137. Teh MT and Sugden D. (1999) The putative melatonin receptor antagonist GR128107 is a partial agonist on Xenopus laevis melanophores. Br. J. Pharmacol. 126: 1237-45 [PMID:10205014]

138. Ting KN, Blaylock NA, Sugden D, Delagrange P, Scalbert E and Wilson VG. (1999) Molecular and pharmacological evidence for MT1 melatonin receptor subtype in the tail artery of juvenile Wistar rats. $\mathrm{Br} \mathrm{J}$ Pharmacol 127: 987-995 [PMID:10433507]

139. Ting KN, Dunn WR, Davies DJ, Sugden D, Delagrange P, Guardiola-Lemaître B, Scalbert E and Wilson VG. (1997) Studies on the vasoconstrictor action of melatonin and putative melatonin receptor ligands in 
the tail artery of juvenile Wistar rats. Br. J. Pharmacol. 122: 1299-306 [PMID:9421275]

140. Tosini G, Owino S, Guillaume JL and Jockers R. (2014) Understanding melatonin receptor pharmacology: latest insights from mouse models, and their relevance to human disease. Bioessays 36: 778-87 [PMID:24903552]

141. Valenti S, Thellung S, Florio T, Giusti M, Schettini G and Giordano G. (1999) A novel mechanism for the melatonin inhibition of testosterone secretion by rat Leydig cells: reduction of $\mathrm{GnRH}$-induced increase in cytosolic Ca2+. J. Mol. Endocrinol. 23: 299-306 [PMID:10601975]

142. Vanda Pharmaceuticals. Tasimelteon Advisory Committee Meeting Briefing Materials.

143. Vanecek J. (1998) Cellular mechanisms of melatonin action.Physiol. Rev. 78: 687-721 [PMID:9674691]

144. von Gall C, Garabette ML, Kell CA, Frenzel S, Dehghani F, Schumm-Draeger PM, Weaver DR, Korf HW, Hastings MH and Stehle JH. (2002) Rhythmic gene expression in pituitary depends on heterologous sensitization by the neurohormone melatonin. Nat Neurosci 5: 234-238 [PMID:11836530]

145. Wang LM, Suthana NA, Chaudhury D, Weaver DR and Colwell CS. (2005) Melatonin inhibits hippocampal long-term potentiation. Eur. J. Neurosci. 22: 2231-7 [PMID:16262661]

146. Weaver DR and Reppert SM. (1996) The Mel1a melatonin receptor gene is expressed in human suprachiasmatic nuclei. Neuroreport 8: 109-12 [PMID:9051762]

147. Weil ZM, Hotchkiss AK, Gatien ML, Pieke-Dahl S and Nelson RJ. (2006) Melatonin receptor (MT1) knockout mice display depression-like behaviors and deficits in sensorimotor gating. Brain Res. Bull. 68: 425-9 [PMID:16459197]

148. Witt-Enderby PA and Dubocovich ML. (1996) Characterization and regulation of the human ML1A melatonin receptor stably expressed in Chinese hamster ovary cells. Mol. Pharmacol. 50: 166-74 [PMID:8700109]

149. Yasuo S, Yoshimura T, Ebihara S and Korf HW. (2009) Melatonin transmits photoperiodic signals through the MT1 melatonin receptor. J. Neurosci. 29: 2885-9 [PMID:19261884]

150. Yous S, Andrieux J, Howell HE, Morgan PJ, Renard P, Pfeiffer B, Lesieur D and Guardiola-Lemaitre B. (1992) Novel naphthalenic ligands with high affinity for the melatonin receptor. J. Med. Chem. 35: 1484-6 [PMID:1315395]

151. Zlotos DP, Attia MI, Julius J, Sethi S and Witt-Enderby PA. (2009) 2-[(2,3-dihydro-1H-indol-1yl)methyl]melatonin analogues: a novel class of MT2-selective melatonin receptor antagonists. J. Med. Chem. 52: 826-33 [PMID:19193160]

152. Zlotos DP, Jockers R, Cecon E, Rivara S and Witt-Enderby PA. (2014) MT1 and MT2 melatonin receptors: ligands, models, oligomers, and therapeutic potential. J. Med. Chem. 57: 3161-85 [PMID:24228714] 